\title{
EdD Graduate Perspectives: Uplifting Our Own Voices
}

\author{
Staci B. Martin, EdD \\ Portland State University \\ mar24@pdx.edu \\ Kara Gournaris, EdD \\ Western Oregon University \\ gournark@mail.wou.edu \\ Zafreen Jaffery, EdD \\ Behavioral Science Research Institute \\ zjaffery@bsrinstitute.org \\ Lisa Hatfield, EdD \\ Oregon Health Sciences University \\ hatfiell@ohsu.edu
}

\author{
Su-Jin Jung, EdD \\ Portland State University \\ sujinj@pdx.edu \\ Li Xiang, EdD \\ Western Michigan University \\ lxiang12@gmail.com \\ Ingrid Anderson, EdD \\ Portland State University \\ ianderson@pdx.edu \\ Micki M. Caskey, PhD \\ Portland State University \\ micki.caskey@gmail.com
}

\begin{abstract}
The purpose of this essay is to share the voices of EdD graduates who are often underrepresented or missing in the literature. To begin, we invited EdD graduates to co-author this article about the connection among their EdD program experiences and interactions and their activism. We included our definition of activism and posed three open-ended questions. Six program graduates and one professor agreed to organize the graduates' responses by the question topics and salient themes. We asked about our experiences in the EdD program and how these influence-positively and negatively—what we are doing now (post-program). We found (a) relationships with faculty and cohort mattered; (b) instructional scaffolding was vital; and (c) faculty and cohorts reflected how lived experiences cultivated a sense of belonging and collectiveness. We also asked about our interactions with peers, cohort, advisor(s), instructors, or mentors, as well as, in what ways did these interactions affect-positively and negatively—what we are doing now (post-program). Lastly, we asked, in what ways, did the EdD program affect-positively or negatively_our activism in the classroom, community, or place of employment. We found examples of how we are shifting the landscape of academia to honor more voices in research and publication, more culturally responsive to impacted communities, and challenging the status quo. We focused on our experiences and interactions in an EdD program and how these experiences and interactions prompted activism in our current practice so that having a diversity of voices not only challenge other students, regardless of their background, to think differently about who creates, produces, and defines knowledge, as well as, support faculty that say they want to expand their curriculum and instruction, yet rely on what they know or what was taught to them in their courses.
\end{abstract}

\section{KEYWORDS}

activism, EdD graduates, underrepresented students, experiences, interactions

The Carnegie Project on the Education Doctorate, Doctorate in Education $(E d D)$ programs make a difference in the nature of educational research because of their scholar-practitioner stance that considers students' professional and personal backgrounds as an integral part of their educational and development process (Purinton, 2012). While postbaccalaureate students are increasingly diverse (McFarland et al., 2019), faculty diversity and curriculum content often do not reflect the lived experiences or cultural context of these students. The problem manifests as differences that create barriers for postbaccalaureate students of color as faculty and persons in positions of power in higher education institutions remain predominantly White (Espinosa et al., 2019; Jaeger \& Haley, 2016; Li $\&$ Koedel, 2017). To address this problem, we highlight and uplift our voices -- primarily voices of color -- to offer a space that affirms students' racial, gender, cultural, and other identities (Egalite \& Kisida, 2018; Gay, 2000; Gershenson et al., 2016; Wang \& Li, 2011). In this essay, we position EdD scholar-practitioners of color and other underrepresented groups as exemplars of what graduates from EdD programs contribute to the field, and specifically, how they make contributions in their practice. We contend that predominantly White faculty could share these examples from EdD scholarpractitioners of color with their diverse cohorts of doctoral students (Lei et al., 2011).

The purpose of our research was to share the voices of EdD graduates who are often underrepresented or missing in the
New articles in this journal are licensed under a Creative Commons Attribution 4.0 United States License. Program and is cosponsored by the University of Pittsburgh Press. 
literature. EdD graduates of color and underrepresented communities are often the subjects of research; we want to shift this dynamic so they are the researchers and authors of publications. In particular, we wanted to foreground underrepresented communities including graduates of color, international graduates, multilingual and/or multicultural graduates, and a graduate from the Deaf Community. To this end, we emphasized the power of writing collaboratively (Ens et al., 2011) as an approach to bring forward the voices of underrepresented communities.

\section{THEORETICAL FRAMEWORK}

We used situated learning theory (Lave \& Wenger, 1991) to frame our research and guide our thinking about EdD graduates who are missing or underrepresented in the literature. In situated learning theory, Lave and Wenger (1991) posited that learning is socially constructed through legitimate peripheral participation "engagement in social practice that entails learning as an integral constituent" (p. 35). As such, learning occurs when individuals engage with others in activities, settings, and situations in which they would typically use their knowledge. Situated learning often happens in a community of practice where a group of people share a common concern or passion for their practice and seek ways to improve their practice by interacting with one another (Wenger, 1998). In our study, the community of practice included EdD scholar-practitioners of color and other underrepresented groups who worked collaboratively to make sense of knowledge within higher education contexts.

In this collective essay, we feature our seldom-heard voicesvoices from one or more of the aforementioned underrepresented groups-regarding our experiences and interactions in an EdD program and how these experiences and interactions prompted activism in our current practice. In our community of practice, we focus on activism because of its centrality in the work of scholarpractitioners. In addition, for our essay, we use a broad definition of activism. We contend that activism encompasses the expansion of personal and professional agency (Quinn \& Carl, 2015) that consists of actionable steps. These actions push against the status quo and create spaces that we co-create with our colleagues or community that lead to individual or collective action. We acknowledge scholars who have explored teacher activism (e.g., Picower, 2012) and others who examined activism in cohorts of social work graduate programs (e.g., Dodd \& Mizrahi, 2017); however, our specific focus is activism among graduates of an EdD program. The graduates share the common context of an EdD program that is a member of the Carnegie Project on the Education Doctorate (CPED) knowledge forum (CPED, 2019).

\section{METHODS}

We used a qualitative and collaborative research approach to explore the voices of underrepresented EdD graduates. Our research explored the ways in which our EdD program affected our sense of agency and activism. Using this approach, we (Staci and Micki) invited EdD graduates from underrepresented communities (i.e., graduates of color, international graduates, multilingual and/or multicultural graduates, a graduate from the Deaf Community) to engage in our exploration. To gather data about the problem of missing voices, we developed and shared three open-ended questions. Accepting our invitation and responding to the questions, signaled the willingness of EdD graduates from underrepresented communities to be our co-researchers and coauthors; their identities and narratives are part of this essay. During any time and for any reason, co-authors could withdraw from the collaboration at which point the lead author(s) would remove relevant names and quotes from the essay.

Because we were interested in EdD graduates' experiences and interactions that supported their activism, we wanted to highlight specifically EdD graduate activism in underrepresented communities. Along with our invitation, we offered our definition of activism and posed three open-ended questions.

We want you to share your stories of becoming "activists" within your current context---the community in which you serve. We are curious about if the EdD program made an impact on your sense of agency and activism.

1. Thinking back on your experience in the EdD program (e.g., activities [agency and identity projects, IRB application, mini-research project, book review), how did these influence--positively and negatively--what you are doing now (post-program)?

2. Now, consider the interactions you had in the EdD program. Think about your interactions with your peers, cohort, advisor(s), instructors, and/or mentors. In what ways did these interactions affect--positively and negatively--you and what you are doing now (postprogram)?

3. In what ways, did the EdD program affect--positively or negatively--your activism in the classroom, community, or place of employment?

Staci and Micki coded the data generated from the three questions. Then, we shared our themes with the rest of the group of co-authors to see if there are any missing themes. Next, we co-wrote the essay and at the final stage, co-authors reviewed and edited the manuscript. Six EdD graduates and one professor (all of the coauthors) agreed to organize the graduates' responses by the question topics and salient themes (e.g., relationships, scaffolding).

We selected this collaborative research approach based on "Speaking for Ourselves Action Research" (SOAR)-a process of how a small group of people from an impacted community identifies the problem (Martin et al., 2018. In her prior research, Staci had the entire impacted group code alongside her. Although the SOAR approach took a considerable amount of time, care, and patience, the approach positioned co-authors with the authority in the analysis process and writing, in turn, co-creating spaces that represent their experiences authentically within education research.

\section{Participants}

Our study consisted of seven womxn, including five womxn of color and six womxn who are multi-lingual (e.g. Hindi, Korean, Mandarin, Punjabi, American Sign Language, Spanish, and Urdu) and bicultural. In some ways, we are "border crossers" (Giroux, 1994) when it comes to navigating bicultural histories and experiences. We have a total of over 75 years amount of teaching at a post-secondary education that stem from K-12 preservice and/or in-service teachers to cross-cultural communication to early childhood education to refugee education to EdD programs. Our research spans from co-researching with vulnerable communities so that they can share their inherent expertise and co-produce knowledge to holding space for those whose voices are marginalized 
under the dominant narrative of education. Other co-authors focus on teacher's identities, in particularly, Chinese language teachers' teaching identity to being a researcher in American Sign Language community especially using the Community of Practices theory since there is no specific research focus in this field. Several co-authors conduct evaluations in the health and education sectors as they attempt to find solutions to the toughest problems faced by women, children, and those from marginalized groups. Other co-authors address how language and cultural learning experiences are related to U.S. education and schooling. Another co-author creates conceptual frameworks that involve the whole learner to advance the scholarship of teaching and learning.

\section{INFLUENCE OF EDD PROGRAM EXPERIENCES ON CURRENT PRACTICE}

When we asked about our collective experiences in the EdD program, we wondered how these influence-positively and negatively-what we are doing now (post-program). When coauthors answered the prompts, we identified three themes: (a) relationships with faculty and cohort mattered; (b) instructional scaffolding was vital; and, (c) faculty and cohorts reflected how lived experiences cultivated a sense of belonging and collectivism. These three components connect to and impact activism because they support EdD students, now graduates, in a third space (Bhabha, 1994) that provides an impetus to achieve institutional stability, cocreates spaces to become advocates for themselves, and negotiates an alternate position of visibility in the academy where they are seen as the experts.

\section{Relationships/Cohort and Faculty}

Relationships in the EdD Program were critical to the graduates' and professors' experiences. Researchers and scholars (Hilliard, 2012; Lee, 2008; Paré, 2011; Simpson \& Matsuda, 2008) explained the importance of how establishing and maintaining professional, positive relationships among faculty and doctoral students helps to ensure the student receives relevant academic support. The faculty, in particular, the dissertation advisor and committee members, played a central role in the doctoral students' experiences and success. Doctoral programs had the ability to position doctoral students as colleagues "engaged in a shared, unequal, and changing practice" (Kamler \& Thomson, 2008, p. 507). In addition, researchers (Amrein-Beardsley et al., 2012; Bista \& Cox; 2014) found that doctoral cohorts promote supportive and collegial relationships among doctoral students and faculty.

Zafreen shared, "Three professors were instrumental and continue to be an inspiration in my development as an international scholar of color." Kara added, "From the very beginning...my advisors, instructors, and peers, made me feel welcome and included." Li shared:

I like the interactions with my cohort members and instructors. I especially like the writing group and peer editing. In my teaching, I use peer editing on my students when there is a writing assignment. Peer editing can help students improve their writing. Sometimes students value their peer's comment more than their instructor's feedback.

With regard to the cohort, Micki revealed, "We-students and instructors-forged long-lasting relationships given our shared learning experiences in our Friday night seminars. We continue to enjoy these post-graduation." Relationships were fundamental to the success of EdD students. We also found that instructional scaffolding played a critical role in supporting students' confidence, agency, and direction.

\section{Instructional Scaffolding}

While Micki used instructional scaffolding to support doctoral student development as researchers and writers, so did other professors. Researchers explicated the value of writing scaffolds (e.g., Ahern \& Manathunga, 2004; Aitchison \& Lee, 2006; Caskey \& Stevens, 2016), and a cognitive apprenticeship pedagogical model (e.g., Collins et al., 1991) for improving doctoral student writing and program completion (Austin, 2009; Caskey \& Stevens, 2019).

Zafreen reported how one professor:

...consistently taught every tool available in her toolkit to allow her students to access the seemingly mysterious task of academic writing. She shared templates, discussed resources and made visible her own process to empower her students. I keep a journal and have a writing habit because of what she has taught me.

Lisa remarked:

The IRB application process was invaluable. I am the director of a teaching and learning center and am advocating scholarship in our work. We must share with the world the work we are doing so that not only others can learn from it and potentially transfer to their own contexts but that we also try to make sense of the effectiveness and impact of our work. No one else on my team had gone through the IRB process when I started a year ago; now, we have scholarship as one of our strategic goals, which includes having our center faculty CITI trained.

Su Jin shared:

I enjoyed participating in writing groups while I was in the EdD program. The writing group that consists of 3-4 people is a support group of writing projects. The writing group members shared google spreadsheets to set weekly writing goals and met regularly to talk about our writing processes, to share our own writing tips and resources, to discuss specific writing concerns, and to provide helpful feedback by reviewing our drafts. Staying connected with my writing group members helped me to complete all the doctoral work successfully by having a good writing habit. Because I know the huge benefits of being a writing group member, I am a writing group member through the faculty writing workshops at PSU. Also, I strongly recommended my graduate students to participate in writing groups in my action research proposal class last year.

While Ingrid remarked:

During the first year of the program, there were several faculty guides that supported my eventual victorious emergence from higher education. During the first year of the program, there were several faculty who served as guides/mentors that supported my eventual victorious emergence from higher education. My guides either taught me to scaffold the new language of the academy that I needed to learn or provide collaborative support with new ways of navigating the doctoral experience. The roadmap that they provided was the only thing that kept me from being lost.

Guides or teachers come in all shapes and forms. For some of the co-authors, they explained how being surrounded by a group of people with lived experiences similar to their own offered space to belong, to create, and to just be. 


\section{Lived Experience}

Our co-authors shared that it was important that their lived expertise are valued, responded to and reflected in the EdD curriculum, as well as, in the research they did. Researchers (e.g. Ladson-Billings, 1992; Gay \& Kirkland, 2003; Savage et al., 2011) recognized the importance of not only representation in the curriculum and instruction, but also for valuing their lived experiences as credible.

\section{Kara remarked:}

I was actually thrilled to find out that several other cohort members had English as their second language, too! I was not alone....Rather than viewing my non-native English skills as an indication that I was less intelligent or less qualified to be part of the program, I found that people acknowledged my expertise in American Sign Language, and recognized the unique lens I brought to the field as a second-generation Deaf woman.

Ingrid's sentiments explained that she chose the EdD program because she was looking for community when she said:

Moving to Oregon, at 42 years of age, created a sense of loneliness that I did not expect. Set adrift from my cultural foundation, I decided to join the EdD program in part because of the need to become part of a new community...As a student, I sought to make connections with others in my cohort. Over time, I discovered while coming from radically different backgrounds, the unique experiences of an EdD program makes for a strong sense of collective that while not always assuring our mutual success, acknowledge our mutual survivorship.

Zafreen explained the importance of having her research approach represented by someone who had first-hand experience, when she said:

I am also grateful for a doctoral dissertation committee structure that provided me with the flexibility to recruit a Professor from the School of Urban Studies and Planning at PSU who had a unique lens and first-hand understanding of conducting field-based research in the South Asian context.

Having students and graduates see themselves reflected in their cohort, teachers, and/or researchers in the field affirms their values, enhances the educational experiences of both learner and teacher, and often forces teachers to re-examine their own biases and complicity in maintaining the status quo.

\section{INFLUENCE OF EDD PROGRAM INTERACTIONS ON CURRENT PRACTICE}

We asked about our interactions with peers, cohorts, advisor(s), instructors, or mentors. We wondered, in what ways these interactions affect-positively and negatively-what we are doing now (post-program). When co-authors answered the prompts, we found numerous examples of how people influenced us and shifted our thinking about ourselves. Zafreen noted deep and personal interactions with her professors:

My professors opened their homes and hearts for me, which was critical for my success as an international student. They invited me for gatherings at their homes and always made sure that I had moral and emotional support available. They offered me genuine kindness, compassion, and understanding.
She disclosed that after graduation, another professor "invited me for tea to offer support and encouragement during a rough transition." Kara also described interactions with her professors:

...they looked me directly in the eyes and saw me for exactly who I was. They asked questions about how best to work with the interpreters, checked in about the types of accommodations I needed, and made sure to include me in every aspect of the program

While Ingrid remarked on how she learned both what she might do and what was not ideal from her relationships with professors, when she said:

I was able to take this [past professors' relationships] forward into my own experiences in teaching and advising students. I spend hours with students a week in advising to help them decode their experiences and receive the support they need in higher education. I want students to thrive and I work to impact their experiences and support them by listening, sharing my own lessons and/or offering navigational tips for academic success, while holding the confidentiality of the students.

Relationships appeared to affect us deeply. Often professors rarely know how they have made a difference in our lives, but it is clear they do.

\section{EFFECT OF EDD PROGRAM ON ACTIVISM IN CURRENT PRACTICE}

We also wondered, in what ways, the EdD program affectedpositively or negatively_our activism in the classroom, community, or place of employment. When co-authors answered the prompts, we found examples of how we are shifting the landscape of academia to honor more voices in research and publication, more culturally responsive to impacted communities, and challenging the status quo.

Ingrid spoke about her journey as an activist and how it evolved when she was an EdD student and currently as an Assistant Professor of Practice when she said,

An EdD program teaches you to critically examine the world.

From my EdD program and the constant and unwavering support of my advisors, now 5 years + graduation, I have developed a scholarship agenda that feeds who I am as an educator. It is this foundation that supports my research in the emotional lives of educators. The collaboration with educators on the emotional labor of teaching emerged from my own experiences of inquiry, disequilibrium, and a strong grounding in phenomenology that I experienced as a doctoral student. These are the foundations of my practice now. I would not be the thinker I am, without my mentors, who to this day remain my champions and co-thinkers.

Kara encompassed activism when she started her EdD program and continued beyond, due to the literature and research being largely absent of voices like hers, when she said:

I ultimately decided to face my fears because I recognized the existing gaps in research related to American Sign Language [ASL] instruction at the post-secondary level, and I wanted to contribute to that field of study. I remember feeling so selfconscious about my writing, and about the fact that I would be the only Deaf person at a hearing university.

She later continued:

My experience in the EdD program was not only transformative for me but for students and faculty at my institution and the local Deaf community. Understanding how 
to better situate my research and instruction, allowed me to advocate for local community events that have had a farreaching impact on members of the Deaf community and students in our program. These community events are student-centered, immersion-based opportunities for Deaf and hearing communities to bridge language and cultural gaps. This EdD program provided the foundations and modeling that I needed to improve my teaching, advocacy, and research practices in the classroom, in my position at the university, and in my role as a leader in the Deaf community.

This led her to embark on a journey that inserted herself in this field of research and forced the field to hear her both figuratively and literally. Because of her unique positionality, she advocated for a third space (Bhabha, 1994) for students who are learning about ASL. She explained, "Many ASL classes require hearing students to attend Deaf events, but this has led to a decrease in opportunities for Deaf space because hearing students sometimes outnumber Deaf people at the events." This outnumbering by the hearing students creates a burden on the Deaf Community (Holcomb, 2017). Having access to native language models is essential in second-language acquisition, so is finding a way to honor Deaf space. However, providing students with a way to engage with members of the Deaf Community (Krashen, 1988) is an ongoing challenge for many of the Deaf communities.

Kara also established a professional community of practice focused on identifying the changing landscape of educating third year ASL students. The intent behind this Think Tank is to discuss pedagogy, resources, and materials needed to bridge the gap in current professional practice (Lave, 1991). Overall, the EdD program helped Kara's activism by offering space for her:

...to assess my own frames, biases, pedagogical approaches, and belief systems as they relate to me personally and professionally...[tt] allowed me to dismantle many of my old beliefs about my inability to contribute to the field of research and scholarship because of my English skills. This program allowed me to find my voice, as an educator, a scholar, and as a leader in my community.

This sentiment of individual agency with a collective social justice slant was a current theme throughout the questions answered. Zafreen reported applying:

...critical theory and research, which has enabled me to give voice to my activism through the lens of social justice and equity. I also learned from my Professor the critical awareness to identify disparities.

She continued:

I conduct research and evaluation for a non-profit focusing on increasing health care and education access. I advocate for disaggregating data to analyze how provisions of policies and programs impact sub-groups disproportionately. Recently, inspired by environmental activism, I have worked to revitalize a community garden in an impoverished and historically African-American neighborhood in Miami. Additionally, I have been developing an environmental education curriculum to be piloted via learning gardens in three elementary schools in Miami that cater to children from low-income backgrounds.

$\mathrm{Li}$ also recognized how theory and practice are brought together to promote social action. She said, "With more knowledge of learning theories, I purposefully use different learning strategies to help my students to learn." Not only with theory, this also was seen in practice, as Li continues to pay more attention to the needs of the vulnerable and less represented groups, in particularly with people with disabilities. In China, Deng and Harris (2008) noted in the late 80 s, there was a considerable effort for inclusivity under the Learning in Regular Classrooms (LRC) program, however they explain that there was limited experience and expertise in the special education field where "students with disabilities were ignored in the classroom and often did not receive instruction, because the teachers had neither enough time nor adequate knowledge to help them" (Deng \& Harris, 2006, p. 198). Since Li's EdD program focused on equity and inclusivity, she received the experience and expertise that she needed to support students with disabilities. This is seen when she said:

The EdD program makes me pay more attention to the needs of the vulnerable and less represented groups. I have some students with learning disabilities. I accommodate their needs and give them extra attention in classroom instruction. There is a local weekend Chinese school. Teachers teaching in this school are mostly new immigrants from China, without any knowledge in language teaching. Just moving from China, teaching Chinese language for a couple of hours on weekends might be the only job they could find now. To better help this group of teachers, I volunteered to organize some teaching workshops.

Su-Jin also brought her activism into her practice when she said:

Because I was trained how to conduct educational research through the EdD program, I could easily plan and organize course materials for my action research class last winter. I coached teacher candidates how to conduct an action research by sharing my own research experiences. I could see the positive results through the course evaluation. For example, many students thought that my action research class made a significant contribution to their learning and professional development. I was very happy to see that my research knowledge/skills, which I learned from the EdD program, played significant roles in my students' research learning process.

The EdD program expanded opportunities for both Lisa and Staci to develop concrete legacy materials, policies, and publications that collaboratively bring forth vulnerable voices to the forefront. Lisa explained:

Since emphasizing scholarship within my department, three colleagues have begun research projects with institutional collaborators. One is looking at linguistic trends of narrative medicine notes, which are reflections of students' clinical experiences; the second is shadowing hospitalists to learn about effective teaching in clinical settings; and the third is working on speech-to-text technology for hearing and hearingimpaired learners to develop exceptional communication skills. One colleague has been inspired to begin a certificate program in narrative medicine, which brings the "powerful narrative skills of radical listening and creativity from the humanities and arts to address the needs of all who seek and deliver healthcare" (Columbia University School of Professional Studies).

Whereas, Staci attempted to co-create space for underrepresented and resilient communities' voice by co-researching, co-presenting (e.g., Martin \& Umubyeyi, 2019), and co-publishing in academic papers (e.g., Martin et al., 2019). She is critically aware that most often research is on a population. As a learner, educator, and researcher, the EdD program reinforced her belief that without collaborating with participants in the research process and the writing itself, "their voices will be muted in the academic language 
describing them and the dominant narrative that disempowers them" (Martin \& Umubyeyi, 2019, p. 123).

Writing this essay with a group of accomplished, resilient, and smart educators and researchers is also an act of activism. We are co-creating spaces for people to have meaningful conversations that go beyond just the peripheral and focus on the lived experiences of made vulnerable EdD graduates.

\section{CONCLUSION}

The purpose of our research was to share the voices of graduates of an EdD program who are often absent from the literature. While researchers often study or talk about underrepresented communities in their research, these communities are rarely the researchers themselves, or authors of the publications. We wanted to foreground our community of practice (Wenger, 1998) of underrepresented groups including graduates of color, international graduates, multilingual and/or multicultural graduates of color, and a graduate from the Deaf Community. In this essay, we uplifted our voices-ones often underrepresented or missing in the literature. We focused on our situated learning experiences and interactions (Lave \& Wenger, 1991) in an EdD program and the way these experiences and interactions prompted activism in our current practices. In doing so, we brought a diversity of voices that not only challenge other students, regardless of their background, but also called on them to think differently about who creates, produces, and defines knowledge. Our aim was to support faculty who say they want to expand their curriculum and instruction, yet tend to rely solely on what they know or what they learned in their academic programs.

\section{REFERENCES}

Ahern, K., \& Manathunga, C. (2004). Clutch-starting stalled research students. Innovative Higher Education, 28(4), 237-254.

Aitchison, C., \& Lee, A. (2006). Research writing: Problems and pedagogies. Teaching in Higher Education, 11(3), 265-278. https://doi.org/10.1080/13562510600680574

Amrein-Beardsley, A., Zambo, D., Moore, D. W., Buss, R. R., Perry, N. J., Painter, S. R., Carlson, D. L., Foulger, T. S., Olson, K., \& Puckett, K. S. (2012). Graduates respond to an innovative educational doctorate program. Journal of Research on Leadership Education, 7(1), 98-122.

Austin, A. E. (2009). Cognitive apprenticeship theory and its implications for doctoral education: A case example from a doctoral program in higher and adult education. International Journal for Academic Development, 14(3), 173-183. https://doi.org/10.1080/13601440903106494

Bhabha, H. K. (1994). The location of culture. Routledge.

Bista, K., \& Cox, D. W. (2014). Cohort-based doctoral programs: What we have learned over the last 18 years. International Journal of Doctoral Studies, 9, 1-20.

Carnegie Project on the Education Doctorate. (CPED, 2019). Carnegie Project on the Education Doctorate (CPED): The knowledge forum on the EdD. Retrieved from http://www.cpedinitiative.org

Caskey, M. M., \& Stevens, D. D. (2016, April). The choppy waters of academic writing for doctoral students: Using writing scaffolds to navigate the journey. Paper presented at the annual meeting of the American Educational Research Association, Washington, DC.

Caskey, M. M., \& Stevens, D. D. (2019, April). Leveraging a cognitive apprenticeship pedagogical model to support doctoral student writing and program completion. Paper presented at the annual meeting of the American Educational Research Association, Toronto, Canada

Collins, A., Brown, J. S., \& Holum, A. (1991). Cognitive apprenticeship: Making thinking visible. American Educator, 15(3), 6-11.
Deng, M. \& Harris, K. (2008 Summer). Teacher Education and Special Education, 31(3), 195-207.

Egalite, A. J., \& Kisida, B. (2018). The effects of teacher match on students' academic perceptions and attitudes. Educational Evaluation and Policy Analysis, 40(1), 59-81.

Ens, A. H., Boyd, K., Matczuk, L. A., \& Nickerson, W. T. (2011). Graduate students' evolving perceptions of writing collaboratively. Canadian Journal of Higher Education, 41(2), 62-81.

Espinosa, L., Turk, J. M., Taylor, M., \& Chessman, H. M. (2019). Race and ethnicity in higher education: A status report. Retrieved from https://1xfsu31b52d33idlp13twtos-wpengine.netdna-ssl.com/wpcontent/uploads/2019/02/Race-and-Ethnicity-in-Higher-Education.pdf

Dodd, S. J, \& Mizrahi, T. (2017). Activism before and after graduate education: Perspectives from three cohorts of MSW students. Journal of Social Work Education, 53(3), 503-519. https://doi.org/10.1080/10437797.2016.1272514

Gay, G. (2000). Culturally responsive teaching: Theory, research, and practice (Multicultural education series). Teachers College Press.

Gay, G., \& Kirkland, K. (2003). Developing cultural critical consciousness and self-reflection in preservice teacher education. Theory Into Practice, 42(3), 181-187.

Gershenson, S., Holt, S. B., \& Papageorge, N. W. (2016). Who believes in me? The effect of student-teacher demographic match on teacher expectations. Economics of Education Review, 52, 209-224.

Giroux, H. A. (1994). Border crossing: Cultural workers and the politics of education. 2nd edition. Routledge.

Hilliard, A. T. (2012). Advising doctorate candidates and candidates' views during the dissertation process. Journal of College Teaching \& Learning, 10(1), 7-12.

Holcomb, T. (2017, June). Required Deaf event attendance: A burden on the Deaf community? Paper presented at the annual conference of the American Sign Language Teachers Association, Salt City, UT.

Jaeger, A. J., \& Haley, K. J. (2016). My story, my identity: Doctoral students of color at a research university. Qualitative Research in Education, 5(3), 276-308. https://doi:10.17583/qre.2016.2019

Kamler, B., \& Thomson, P. (2008). The failure of dissertation advice books: Toward alternative pedagogies for doctoral writing. Educational Researcher, 37(8), 507-514

Krashen, S. D. (1988). Second language acquisition and second language learning. Prentice-Hall International.

Ladson-Billings, G. (1992). Reading between the lines and beyond the pages: A culturally relevant approach to literacy teaching. Theory into Practice, 31(4), 312-320.

Lave, J. (1991). Situating learning in communities of practice. Perspectives on Socially Shared Cognition, 2, 63-82.

Lave, J., \& Wenger, E. (1991). Situated learning: Legitimate peripheral participation. Cambridge University Press.

Lee, A. (2008). How are doctoral students supervised? Concepts of doctoral research supervision. Studies in Higher Education, 33(3), 267-281. https://doi.org/10.1080/03075070802049202

Lei, S., Gorelick, D., Short, K., Smallwood, L., \& Wright-Porter, K. (2011). Academic cohorts: Benefits and drawbacks of being a member of a community of learners. Education, 131(3), 497-504.

Li, D., \& Koedel, C. (2017). Representation and salary gaps by race-ethnicity and gender at selective public universities. Educational Researcher, 46(7), 343-354. https://doi.org/10.3102/0013189X17726535

Martin, S. B., Burbach, J. H., Lares Benitez, L., \& Ramiz, I. (2019). Participatory action research: A tool for bringing youth knowledge to the center of research. London Review of Education on Methodological Innovation, 17(3), 297-313.

Martin, S. B., Warsame, D., Bigirimana, C., Lajustine, V, Teferra, G., Abdi, A., \& Taban, J. (2018, August 4). Kakuma Refugee Camp: Where knowledge and hope resides. In P. Blessinger and E. Sengupta (Eds.). Innovations in Higher Education Teaching and Learning (IHETL): Refugee Education: Integration and Acceptance of Refugees in Mainstream Society, 139-155. Emerald Group Publishing.

Martin, S. B., \& Umubyeyi, V. (2019). What works in education in emergency: Co-researching and co-authoring. In M. Mendenhall (Ed.), NORRAG Special Issue 02 Data Collection and Evidence Building to Support Education in Emergencies, 122-125. Geneva, Switzerland: NORRAG. Retrieved from https://resources.norrag.org/resource/view/525/276 
McFarland, J., Hussar, B., Zhang, J., Wang, X., Wang, K., Hein, S., Diliberti, M., Forrest Cataldi, E., Bullock Mann, F., \& Barmer, A. (2019). The condition of education 2019 (NCES 2019-144). U.S. Department of Education. National Center for Education Statistics. Retrieved from https://nces.ed.gov/pubsearch/pubsinfo.asp?pubid=2019144

Paré, A. (2011). Speaking of writing: Supervisory feedback and the dissertation. In L. McAlpine \& C. Amundsen (Eds.). Doctoral education: Research-based strategies for doctoral students, supervisors, and administrators, 59-74. Springer.

Picower, B. (2012). Teacher activism: Enacting a vision for social justice. Equity \& Excellence in Education, 45(4), 561-574 https://doi.org/10.1080/10665684.2012.717848

Purinton, T. (2012 May 15). The Ed.D. dilemma. Education Week, 31(31), 24 25.

Quinn, R., Carl, N. M. (2015). Teacher activist organizations and the development of professional agency. Teachers and Teaching, 21(6) 745-758. https://doi.org/10.1080/13540602.2015.1044331

Savage, C., Hindle, R., Meyer, L. H., Hynds, A., Penetito, W., \& Sleeter, C. E. (2011). Culturally responsive pedagogies in the classroom: Indigenous student experiences across the curriculum. Asia-Pacific Journal of Teacher Education, 39(3), 183-198.

Simpson, S., \& Matsuda, P. K. (2008). Mentoring as a long-term relationship: Situated learning in a doctoral program. In C. P. Casanave \& X. Li (Eds.). Learning the literacy practices of graduate school: Insiders' reflections on academic enculturation, 90-104. University of Michigan Press.

Wang, T., \& Li, L. Y. (2011). "Tell me what to do" vs. "guide me through it": Feedback experiences of international doctoral students. Active Learning in Higher Education, 12(2), 101-112. https://doi.org/10.1177/1469787411402438

Wenger, E. (1988). Communities of practice: Learning, meaning, and identity. Cambridge University Press. 